\title{
The Role of Assessment as Learning to Support Pre-service Mathematics Teachers in Designing Mathematics Test Instruments Based on ESD
}

\author{
Indah Widiati ${ }^{1,2}$, Turmudi ${ }^{2,}$, Dadang Juandi ${ }^{2}$ \\ ${ }^{1}$ Department of Mathematics Education, Universitas Islam Riau, Jl. Kaharudin Nasution No 113, Pekanbaru 28284, Indonesia \\ ${ }^{2}$ Department of Mathematics Education, Universitas Pendidikan Indonesia, Jl. Dr. Setia Budhi No. 229, Bandung 40154, Indonesia
}

Received August 14, 2020; Revised October 24, 2020; Accepted November 1, 2020

\section{Cite This Paper in the following Citation Styles}

(a): [1] Indah Widiati, Turmudi, Dadang Juandi, "The Role of Assessment as Learning to Support Pre-service Mathematics Teachers in Designing Mathematics Test Instrument Based on ESD," Universal Journal of Educational Research, Vol. 8, No. 12, pp. 6868 - 6884, 2020. DOI: 10.13189/ujer.2020.081253.

(b): Indah Widiati, Turmudi, Dadang Juandi (2020). The Role of Assessment as Learning to Support Pre-service Mathematics Teachers in Designing Mathematics Test Instrument Based on ESD. Universal Journal of Educational Research, 8(12), 6868 - 6884. DOI: 10.13189/ujer.2020.081253.

Copyright $₫ 2020$ by authors, all rights reserved. The authors agree that this article remains permanently open access under the terms of the Creative Commons Attribution License 4.0 International License.

\begin{abstract}
This study aims to describe the role of Assessment as Learning for pre-service mathematics teachers in designing mathematical test instruments. Assessment as Learning is useful as a quality control tool for the designed mathematics test instrument. This is qualitative research with a phenomenological approach, involving four pre-service mathematics teachers. Data were obtained through the design of mathematical test instruments and in-depth interviews with the participants. The test instruments designed was then adjusted to the results of the interview. The research results reveal that Assessment as Learning is important in supporting students to monitor the results of their work; environmental aspects are the most difficult aspects to be integrated into mathematical problems; students have more difficulty in completing Peer-Assessment than Self-Assessment; the problems raised in the economic aspects are only around prices, and Self-Assessment and Peer-Assessment are very helpful in detecting errors and deficiencies in the questions designed. It is concluded that Assessment as Learning helps and supports pre-service mathematics teachers in designing mathematics test instruments to create good quality mathematics test instruments. This research contributes to pre-service mathematics teachers conducting the Assessment as Learning to minimize errors in the mathematical test instruments.
\end{abstract}

Keywords Assessment as Learning, ESD,
Mathematics Teachers, Pre-service, Mathematics, Test Instrument

\section{Introduction}

Assessment is a tool that can strengthen or weaken students' Learning. However, in reality, judgment is not well understood at all levels of life [1]. Assessment is a component that can support Learning. In contrast, assessment can also act as a barrier to Learning if it is not done well. Likewise, classroom assessment can develop students' achievement [2]. Assessment aims to map students' progress and provide feedback so students can improve Learning and help teachers adjust teaching to students' needs [3]. Assessment has a strong influence on the learning process. If the assessment is not well designed, it can damage the teaching and learning process [4]. Thus, assessment has a major role in improving student learning. However, sometimes, assessment weakens student learning.

Assessment plays a role in determining students' learning needs and overcoming students' weaknesses to improve learning [5]. Teachers must develop assessment tasks by activating students' sense of effectiveness in completing assignments and increasing the value of their 
involvement in the task [6]. Therefore, the teacher plays an important role in realizing the success of assessment.

In Indonesia, most teachers only conduct Assessment of Learning, a few do Assessment for Learning in a formative form, and not many do Assessment as Learning [7]. One of the seven feedback in the learning process is facilitating self-assessment in Learning (reflection) [3]. Assessment in higher education institutions tends not to equip the learning process properly. Hence, the assessment should be expanded so that students can carry out ongoing assessments and support the life-long learning process [8]. Thus, the assessment is certainly very supportive of the Education for Sustainable Development (ESD) program.

One of the reasons that assessment can increase students' motivation is that assessment can motivate students to learn better, teachers to teach better, and schools to be more effective in education [9]. Assessment is not only something done to students, but also to assess their performance. When students are given feedback, it is useful for those who receive it and those who give [10]. Assessment has a role in the learning process and is inseparable from the learning process. In fact, assessment should support the learning process to improve students' learning outcomes.

There are six reasons for conducting an assessment, namely: (1) maintaining the learning flow, (2) diagnosing difficulties in reading and writing, (3) determining eligibility for a program, (4) evaluating the program, (5) evaluating Learning, and (6) report to other parties [11]. These rationales indicate that assessment plays an important role, which is only useful before, during, and after the learning process. Therefore, the teachers should understand the assessment and other matters related to it as a whole so that they can apply it appropriately, improving student learning.

Class assessment is an activity (formal or informal) designed by teachers to assess students' learning and to support students' involvement in assessing their learning (through self-assessment and peer-assessment) [12]. The class assessment consists of three types of assessment: Assessment of Learning, Assessment for Learning, and Assessment as Learning [13]. Traditional assessments include Assessment of Learning and Assessment for Learning, and then reconfiguration occurs as Assessment as Learning [13]. Figure 1 illustrates the assessment pyramid [14].

Figure 1 displays the assessment pyramid based on [14]. The pyramid shows that a change between the traditional and the reconfiguration assessment pyramid. In the traditional assessment pyramid, the biggest portion is Assessment of Learning, where the assessment was mostly done after the Learning had been completed. Then, a change in thinking occurred so that the component Assessment as Learning received the largest portion. This means that this assessment is highly sought after so that students participate directly in conducting the assessment during the learning process. Assessment as Learning is currently being pursued so that teachers can implement it in the learning process. Table 1 describes the differences between the three types of assessment [14].

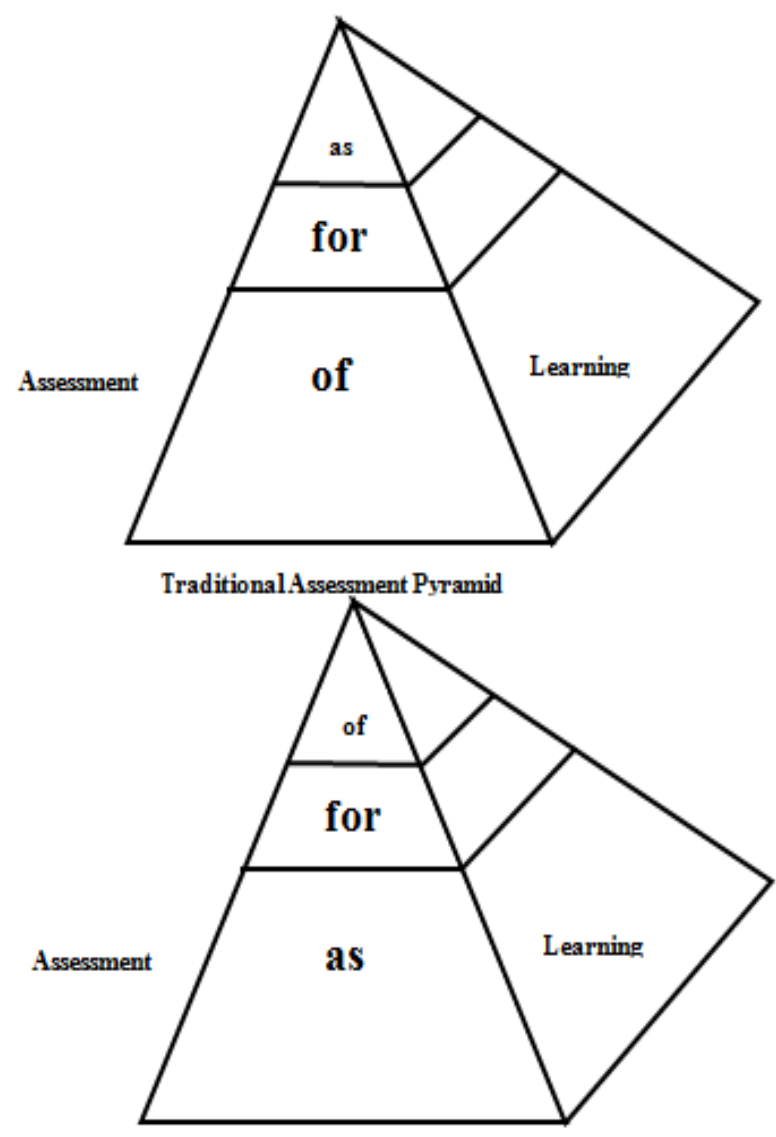

Reconfigurade Assessment Pyramid

Figure 1. Balance Among Assessment Purposes [14]

Table 1. Differences between assessment for, of, dan as Learning [14]

\begin{tabular}{|c|c|c|}
\hline $\begin{array}{c}\text { Assessment for } \\
\text { Learning } \\
\end{array}$ & $\begin{array}{c}\text { Assessment of } \\
\text { Learning } \\
\end{array}$ & $\begin{array}{c}\text { Assessment as } \\
\text { Learning }\end{array}$ \\
\hline $\begin{array}{l}\text { Performed by the } \\
\text { teacher }\end{array}$ & $\begin{array}{c}\text { Performed by the } \\
\text { teacher }\end{array}$ & $\begin{array}{c}\text { Performed by } \\
\text { students }\end{array}$ \\
\hline $\begin{array}{l}\text { To determine the next } \\
\text { steps to be taken }\end{array}$ & $\begin{array}{c}\text { To determine the } \\
\text { level of student } \\
\text { achievement }\end{array}$ & $\begin{array}{l}\text { To determine } \\
\text { the next } \\
\text { learning steps }\end{array}$ \\
\hline \multirow[t]{2}{*}{$\begin{array}{l}\text { To provide feedback } \\
\text { for students (what they } \\
\text { should do, what is } \\
\text { needed to develop, and } \\
\text { how to develop it) }\end{array}$} & $\begin{array}{l}\text { As evidence to } \\
\text { support statements } \\
\text { or theories in a } \\
\text { professional manner }\end{array}$ & $\begin{array}{c}\text { To provide } \\
\text { individual and } \\
\text { peer feedback. }\end{array}$ \\
\hline & & $\begin{array}{l}\text { As a material for } \\
\text { reflection, } \\
\text { monitoring } \\
\text { students by } \\
\text { themselves }\end{array}$ \\
\hline
\end{tabular}

Assessment for Learning and Assessment of Learning are both conducted by the teacher. Assessment of Learning is designed to provide evidence of students' learning achievement to parents, other educators, students, and other educational institutions. It provides reports about 
how well students are learning and make important decisions that will affect students' future. Whereas, Assessment for Learning occurs during the Learning, often done more than once. It is a teacher's tool to examine what students have gained, what confusion they feel, students' preconceptions, and gaps that students might have. Various information about students' learning processes is collected to provide a basis for what they need to do next for student progress.

In Assessment as Learning, the teacher is a guide, "Give students the tools to do their learning wisely and well [14]." Students learn to monitor their Learning and make adaptations as needed. In addition to monitoring learning and guiding instruction through assessments for Learning, teachers assess students' ability to assess themselves when they learn how to assess their Learning.

Assessment as Learning is an assessment by students through self-assessment of the work they have done. Assessment as Learning can be done for any learning process because students should be able to review their work without first asking for validation from the teacher. Assessment as Learning is part of the class assessment and serves to assess student performance in terms of solving the problems given by the teacher. Evaluation of student performance is an important issue in actual education. It is interesting for all components involved in the education process, such as teachers, students, parents, and schools [15]. Likewise, with the implementation of Assessment as Learning where the implementation should receive the attention and support of the teacher as a guide, students are the main actors of this assessment, and parents should also support this assessment. Thus, later parents can find out their child's development also through this Assessment as Learning. Therefore, the difficulties experienced during conducting Assessment as Learning should be anticipated together before the Assessment process is carried out.

Assessment as Learning consists of Self-Assessment and Peer-Assessment. Self-Assessment is a student self-assessment as a form of responsibility for Learning and their performance [16]. If Self-Assessment is used as a process at school and in everyday life, where the student is the center of Learning, then students can participate directly in learning [17]. Peer-Assessment is an arrangement for students to consider and determine the level, value, or quality of a product or the performance of others [18]. Peer-Assessment involves student activities in evaluating the work of their peers [19]. Therefore, Assessment as Learning is basically a process to develop and support student metacognition [14].

In this study, Self-Assessment serves as a tool to evaluate their work results (the design of mathematical test instruments). The peer-assessment functions as a tool for evaluating the work of peers (the design of a mathematical test instrument by colleagues). This repeated evaluation process is expected to reduce errors and deficiencies in the mathematical test instruments designed. So, this will support the quality of the designed mathematics test instruments.

The mathematical test instrument designed in this study is based on Education for Sustainable Development (ESD). ESD has three domains: social, economic, and environmental aspects [20]. These three aspects will support the achievement of 17 Sustainable Development goals, which are (1) no poverty; (2) zero hunger; (3) good health and well-being; (4) quality education; (5) gender equality; (6) clear water and sanitation; (7) affordable and clean energy; (8) decent work and economic growth; (9) industry, innovation and infrastructure; (10) reduced inequalities; (11) sustainable cities and communities; (12) responsible consumption and production; (13) climate action; (14) life below water, (15) life on land; (16) peace, justice and strong institutions; and (17) partnership for the goals [21].

The ESD application in mathematics supports the achievement of the Sustainable Development goal of quality education. The link between mathematics and ESD is continuous Learning and the relevance of mathematics learning applications and character values [22]. When studying mathematics, students acquire mathematics, but there are also character values that emerge as a basis for supporting students' survival.

There are common mistakes in designing mathematics test questions, for example, data errors, writing errors, errors in selecting objects or objects used, the final results not matching reality due to no trial, and other problems. These errors happen because the questions are only designed by themselves without asking for verification or assessment from others. In fact, sometimes, the question is not proofread to ensure that there are no mistakes. Therefore, it is necessary to have an assessment that can support teachers or pre-service mathematics teachers to better design mathematics test questions. It is hoped that this assessment can minimize errors and mistakes and result in more qualified mathematics test questions.

In this study, ESD will be integrated into the design of Mathematical Education test instruments based on ESD. Then, to produce a quality mathematical test instrument design, Assessment as Learning process consists of Self-Assessment and Peer-Assessment. Through this process, the researcher examines the role of Assessment as Learning in supporting the pre-service mathematics teachers in designing Mathematics test instruments based on ESD. The research objectives are also described, so the role and benefits of Assessment as Learning in supporting the learning process are known.

\section{Materials and Methods}

This research is qualitative research with a phenomenological approach. This qualitative study analyzed in depth the results of the study descriptively to construct a conjecture. The participants in this study were 
four pre-service mathematics teachers (student teachers). This research was conducted by asking participants to design a mathematics test instrument for ESD. The pre-service mathematics teachers were asked to compile each mathematics problem in social, economic, and environmental areas. They also conducted self-assessment and peer-assessment processes related to the resulting draft. Based on the data, researchers analyzed the draft of mathematical tests created by the coding process. The coding results were then analyzed whether the character values included so that the question is classified by the mathematics test based on ESD. The data analysis process was carried out based on the codes found in the coding process. After obtaining the data, the researchers conducted in-depth interviews with the participants. This interview aimed to confirm the answers given when designing a mathematics test instrument and dig deeper information to support the results of the mathematics test instrument designed.

The tool used in this study was a test sheet to ask participants to design mathematics test questions in the social, economic, and environmental fields. Other research tools were the self-assessment and peer-assessment sheets. The researcher also used an open and structured interview sheet to explore in-depth information about the participants' answers on the test, self-assessment, and peer-assessment sheets.

\section{Results}

This section describes the research results obtained through the design of mathematics test instruments produced by pre-service mathematics teachers. The results of the research are presented in tables and figures. The presentation of this data is expected to facilitate the readers in understanding the results of the research. The study results include the design of mathematics test questions, along with the Self-Assessment and Peer-Assessment answers given by pre-service mathematics teachers.

Figure 2 presents the design of Mathematics test instruments based on ESD (social aspects) produced by three pre-service mathematics teachers. It indicates that:

a). All question designs contain character values that appear implicitly in the sentence used. The material in AAL-13 should be numbers, not social arithmetic.

b). All test instrument designs are in accordance with the application of mathematical problems in the social aspect. This can be seen from the sentence used. Even though this is a question design to integrate social aspects, it also includes the price of something, but that does not mean that the question design is included in the economic aspect. This can be seen again from the sentence used.

c). All character values used are appropriate for each problem designed. However, other character values that should still be added are not included; for example, in AAL-17, sharing characters or social care can be added.

d). There are inaccuracies in the choice of words in the sentence and the use of punctuation. For example, in AAL-06, there are inaccuracies in the use of the word "by". The word used is "to". AAL-13 incorrectly determines the mathematical material, which should not be social arithmetic.

e). For the accuracy of the data, all of the data plans are correct. This has also been confirmed through interviews with students and data search results by researchers.

From the five points previously described, it can be concluded that pre-service mathematics teachers have been able to design mathematics problems based on ESD for social aspects. The inaccuracies are only concerning the choice of words and punctuation. 


\begin{tabular}{|c|c|c|}
\hline AAL-06 & 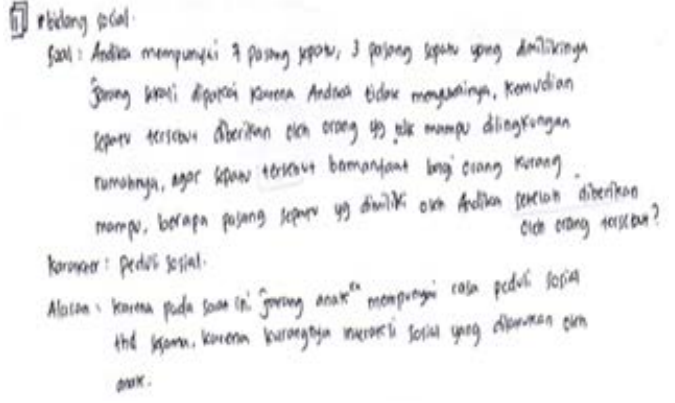 & $\begin{array}{l}\text { Field: social } \\
\text { Problem: Andika has seven pairs of shoes. The three } \\
\text { pairs of shoes he had were rarely used because Andika } \\
\text { did not like them. The shoes are then given to people } \\
\text { who cannot afford it so that the shoes are useful for } \\
\text { poor people. How many pairs of shoes does Andika } \\
\text { have after giving to the people? } \\
\text { Character: social care } \\
\text { Reason: Nowadays, children rarely have a sense of } \\
\text { social care for others due to the lack of social } \\
\text { interaction carried out by children. }\end{array}$ \\
\hline AAL-13 & 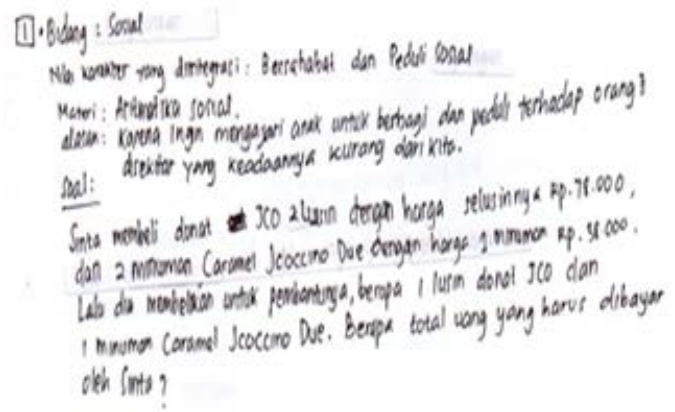 & $\begin{array}{l}\text { Field: social } \\
\text { Character values integrated: friendly and social care. } \\
\text { Material: social arithmetic. } \\
\text { Reason: To teach children to share and care for those } \\
\text { around us who have less privilege than us. } \\
\text { Problem: Sinta buys two dozen JCO donuts at a price } \\
\text { of a dozen, IDR 78,000, and a Caramel Jcoccino Due } \\
\text { drink at a price of one drink, IDR } 38,000 \text {. She also } \\
\text { bought for her maid a dozen JCO donuts and one } \\
\text { Caramel Jcoccino Due drink. What is the total amount } \\
\text { of money that must be paid by Sinta? }\end{array}$ \\
\hline AAL-17 & 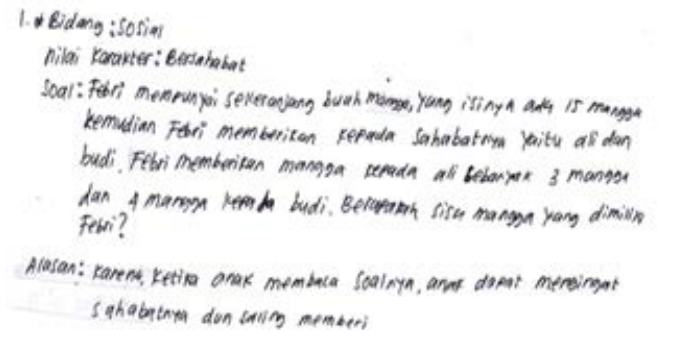 & $\begin{array}{l}\text { Field: social } \\
\text { Character value: friendly } \\
\text { Problem: Febri had a basket of } 15 \text { mangoes, and he } \\
\text { gave them to his best friend, Ali and Budi. Febri gave } \\
\text { three mangoes to Ali and four mangoes to Budi. How } \\
\text { many mangoes Febri had? } \\
\text { Reason: When children read the problem, they can } \\
\text { remember their friends and inspire them to give each } \\
\text { other. }\end{array}$ \\
\hline AAL-21 & 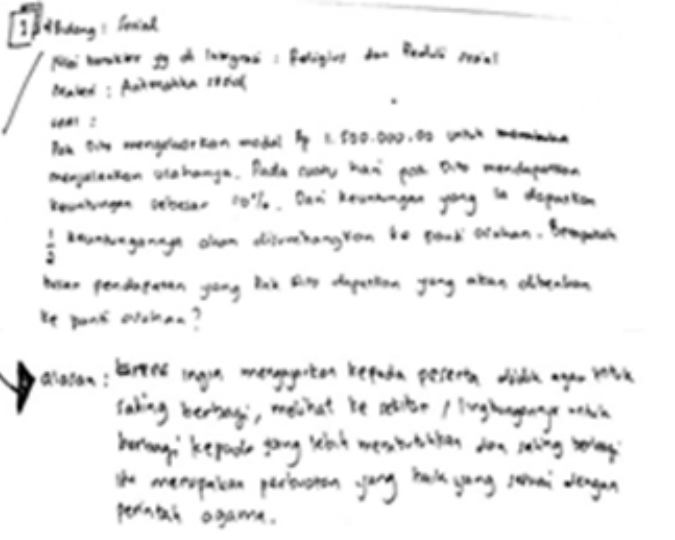 & $\begin{array}{l}\text { Field: social } \\
\text { Integrated character values: religious and social care } \\
\text { Material: social arithmetic } \\
\text { Question: } \\
\text { Pak Dito spent IDR } 1,500,000 \text { in capital to run his } \\
\text { business. One day, Pak Dito got a profit of } 10 \% \text {. He } \\
\text { will donate } 1 / 2 \text { of the profit to the orphanage. How } \\
\text { much will Mr. Dito give to the orphanage? } \\
\text { Reason: To teach students to share, observing their } \\
\text { environment to share with those who need it more, and } \\
\text { sharing is a good deed according to religious teaching. }\end{array}$ \\
\hline
\end{tabular}

Figure 2. Design of Mathematics Test Questions Based on ESD (Social Aspects) 


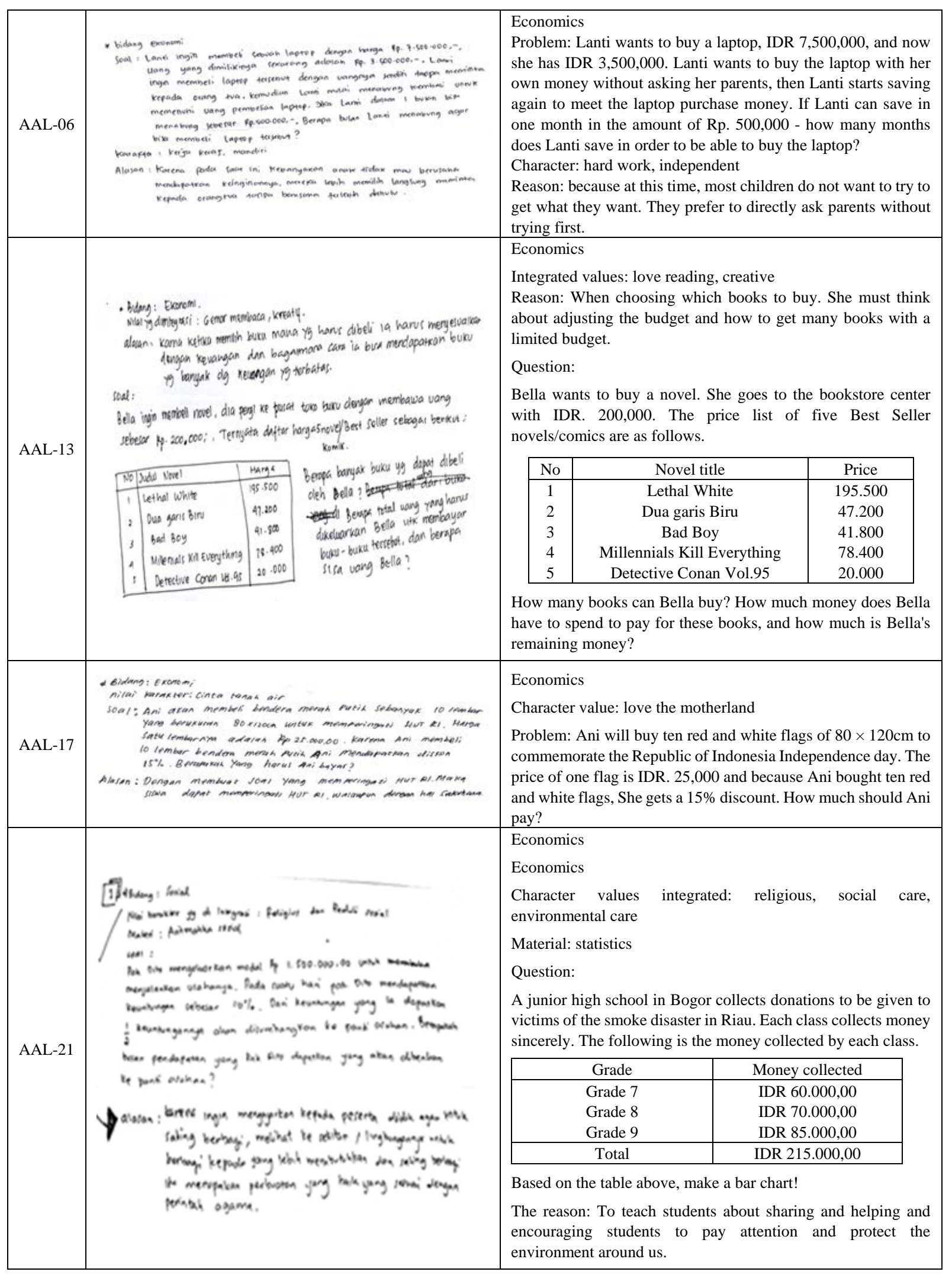

Figure 3. Design of Mathematics Test Questions Based on ESD (Economics Aspects) 
Figure 3 presents the ESD (Economic aspects) based mathematics design produced by six pre-service mathematics teachers, and it indicates that:

a). There is a character value on each question designed.

The character values appear implicitly, not clearly written in sentence used.

b). The mathematical problems used matches with their application in economic aspects. c). There are mistakes in punctuation and capital letters.

In general, the pre-service teachers have been able to design mathematics problems based on ESD. The sample selection and the character value are correct, even though some are missing. The errors are only in punctuation and unit usage.

\begin{tabular}{|c|c|c|}
\hline AAL-06 & 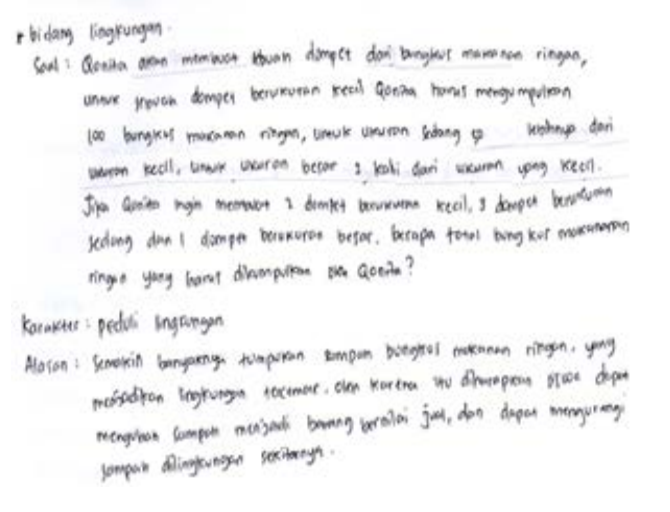 & $\begin{array}{l}\text { Field: Environment } \\
\text { Question: } \\
\text { Qonita will make a wallet from snack packs. For a small wallet, } \\
\text { Qonita will need to collect } 100 \text { packs of snacks. She will need } \\
50 \text { more packs for the medium size and the size of double the } \\
\text { small size. If Qonita wants to make two small wallets, three } \\
\text { medium wallets, and one large wallet, how many total snack } \\
\text { packs should Qonita collect? } \\
\text { Characters: caring for the environment } \\
\text { Reason: there are increasing piles of junk food wraps, which } \\
\text { polluted the environment. Therefore, it is hoped that students } \\
\text { can turn waste into valuable items and reduce waste around } \\
\text { them. }\end{array}$ \\
\hline AAL-13 & 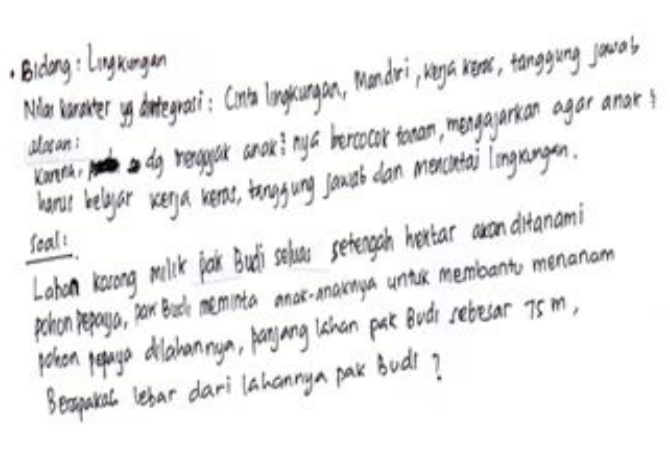 & $\begin{array}{l}\text { Field: environment } \\
\text { Character values integrated: love for the environment, } \\
\text { independent, hard work, responsible. } \\
\text { Reason: } \\
\text { Inviting children to grow crops will teach children about hard } \\
\text { work, responsibility, and love for the environment. } \\
\text { Question: } \\
\text { Mr. Budi's empty land of half a hectare will be planted with } \\
\text { papaya trees. Mr. Budi asks his children to help plant papaya } \\
\text { trees on his land. If Mr. Budi's land length is } 75 \mathrm{~m} \text {, what is the } \\
\text { width of his land? }\end{array}$ \\
\hline AAL-17 & 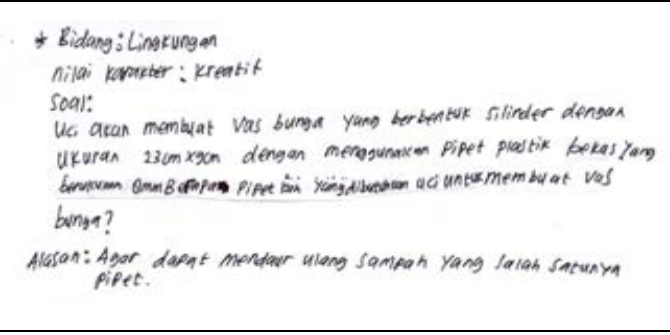 & $\begin{array}{l}\text { Field: environment } \\
\text { Character value: creative } \\
\text { Question: } \\
\text { Uci will make a } 33 \mathrm{~cm} \times 9 \mathrm{~cm} \text { cylindrical flower vase using a } \\
\text { used plastic straw of } 8 \mathrm{~mm} \text {. How many straws does uci need to } \\
\text { make a flower vase? } \\
\text { Reason: to teach children about upcycling garbage, one of } \\
\text { which is a straw. }\end{array}$ \\
\hline AAL-21 & 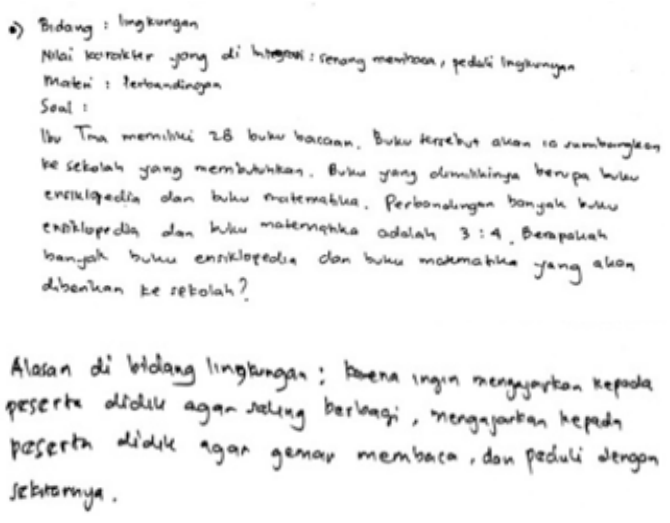 & $\begin{array}{l}\text { Field: environment } \\
\text { Integrated character values: enjoy reading, care for the } \\
\text { environment. } \\
\text { Material: comparison } \\
\text { Question: } \\
\text { Ms. Tina has } 28 \text { books to read. The book will be donated to } \\
\text { schools in need. Her books are encyclopedias and mathematics } \\
\text { books. The comparison of the number of encyclopedias and } \\
\text { mathematics books is 3:4. How many encyclopedias and } \\
\text { mathematics books will be given to schools? } \\
\text { Reason in the environmental field: To teach students to share, } \\
\text { encourage students to like reading, and care about their } \\
\text { surroundings. }\end{array}$ \\
\hline
\end{tabular}

Figure 4. Design of Mathematics Test Questions Based on ESD (Environment Aspects) 
Based on the questions in Figure 4, it can be interpreted that:

a. There is an inaccuracy of the data in the questions designed by AAL-17, where the given cylinder data is length and width. The cylinder should use height and radius or diameter. Then students also acknowledge that there is a lack of data for the straw data. Students only provide diameter data without the height of the straw. The word diameter is also not written. AAL-17 students only write the size without knowing what size it is.

b. As for other students, they have correctly chosen mathematics problems with environmental aspects. Likewise, with the selection of character values.

c. There are still inaccuracies in punctuation and some writing errors. The error is minor, but it affects the accuracy in preparing the question editor.

d. There is incomplete data on AAL-13; that is, the shape of the vacant land is unknown. After being confirmed to students, students said that the vacant land was rectangular.

Question number 1:

"Explain which part of the mathematical problem designed have integrated problems in the social, economic, and environmental fields?"

Table 2 shows the results of students' answers in conducting Self-Assessment. This Self-Assessment serves as a medium for students to review the draft questions they have produced. This first question asks students to detect which parts of the question designed have integrated problems in the social, economic, and environmental fields. Based on students' answers, it can be summarized that:

a. In general, students have been able to detect which parts of their question designed that integrate problems in the social, economic, and environmental fields.

b. There is an incomplete sentence on AAL-17, which is the price of 1 flag. If only the price of one flag is written, then this does not clearly indicate what.

Table 2. Application of Self-Assessment (Question No. 1)

\begin{tabular}{|c|c|c|}
\hline Respondent Code & Mathematical Problem Design & Translation \\
\hline AAL-06 & 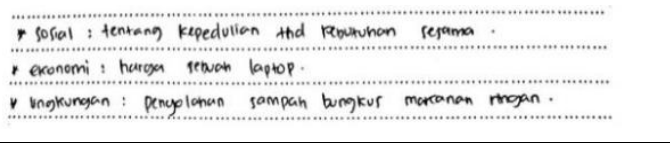 & $\begin{array}{l}\text { Social: about caring for the needs of others } \\
\text { Economy: the price of a laptop } \\
\text { Environment: processing snack food packaging } \\
\text { waste. }\end{array}$ \\
\hline AAL-13 & 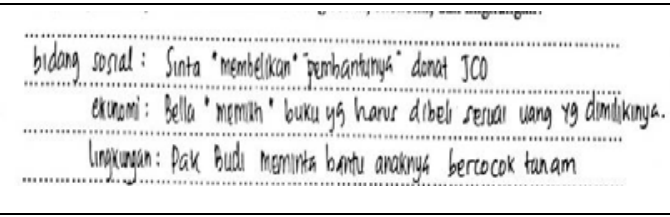 & $\begin{array}{l}\text { The social sector: Sinta buys her maid JCO } \\
\text { donuts. } \\
\text { Economy: Bella "chooses" books to buy according } \\
\text { to the money she has } \\
\text { Environmental sector: Mr. Budi asked for help } \\
\text { from his children to grow crops. }\end{array}$ \\
\hline AAL-17 & 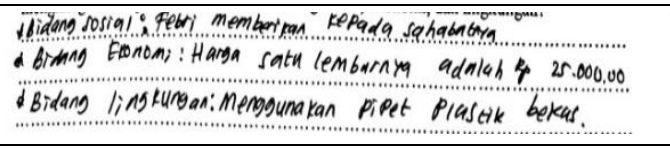 & $\begin{array}{l}\text { The social sector: Febri shares with his best friend } \\
\text { Economics: the price of one share is IDR. } \\
25,000.00 \\
\text { Environmental sector: using used plastic straw }\end{array}$ \\
\hline AAL-21 & 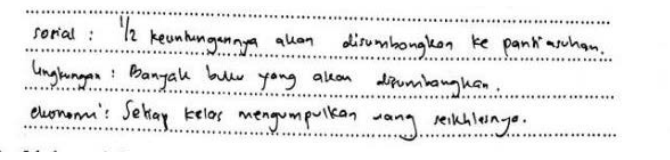 & $\begin{array}{l}\text { Social: } \frac{1}{2} \text { the profits will be donated to the } \\
\text { orphanage } \\
\text { Environment: many books will be donated } \\
\text { Economy: each class collects money sincerely }\end{array}$ \\
\hline
\end{tabular}

Table 3. Application of Self-Assessment (Question No. 3)

\begin{tabular}{|c|c|c|}
\hline $\begin{array}{l}\text { Respondent } \\
\text { Code }\end{array}$ & Answers of Students & Translation \\
\hline AAL-06 & saya us: coba terlevin dowilu temeng soal yang laya buat. & I first tested the problem I made \\
\hline AAL-13 & 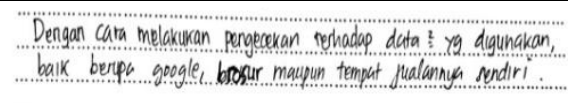 & $\begin{array}{l}\text { By checking the data used, whether from } \\
\text { Google, brochures, or the shop itself. }\end{array}$ \\
\hline AAL-17 & $\begin{array}{l}\text { saya keriakan terlebih dahylu sehingsg says } \\
\text { mengetahui kesalahan dari soal saya }\end{array}$ & $\begin{array}{l}\text { I do it first, so I know any mistake with my } \\
\text { problem. }\end{array}$ \\
\hline AAL-21 & 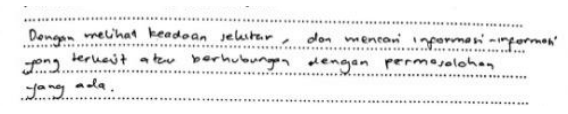 & $\begin{array}{l}\text { By looking at the circumstances and searching for } \\
\text { the information related to existing problems. }\end{array}$ \\
\hline
\end{tabular}


Question number 3:

"How do you re-check the accuracy of the data on the mathematical problem you chose?”

Table 3 shows that students can re-examine the accuracy of the data in the mathematical problems designed. From the answers provided, the following findings are summarized.

a). In general, students have been able to re-examine the questions they produce.

b). They use a variety of examination methods: testing the problem, checking the accuracy of the data by utilizing the internet, working on the questions designed first, and re-examining the data used.

c). Even though students have checked the question designed, there are still unconscious mistakes. For example, AAL-17 shows incomplete and inaccurate data. However, when examining the questions designed themselves, it is identified that students do not realize there are deficiencies and errors in the questions designed. Next, this will be reviewed in the Peer-Assessment and interview results.

\section{Question number 4:}

"How do you ensure that there are no data errors in the problems related to the social, economic, and environmental fields that you choose?"

Table 4 illustrates how students ensure that there are no data errors in the social, economic, and environmental fields. Based on the answers given by students, it is known that students have done a thorough process to ensure the accuracy of the data. For example, when they want to raise a problem theme, they use the media to help them find the data they need. If the data can be arranged or designed by themselves, after the question designed is complete, they validate the data by first working on the problem. With the process of working on the problem in advance, it is expected that the data used are all accurate.

Table 4. Application of Self-Assessment (Question No. 4)

\begin{tabular}{|c|c|c|}
\hline $\begin{array}{l}\text { Respondent } \\
\text { Code }\end{array}$ & Answers of Students & Translation \\
\hline AAL-06 & 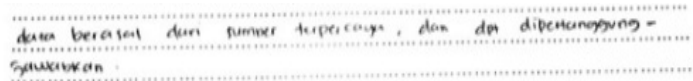 & $\begin{array}{l}\text { Data comes from reliable sources, and can be } \\
\text { justified }\end{array}$ \\
\hline AAL-13 & $\begin{array}{l}\text { Dengan carn mencar data dahulu sebolum menuliskannya didalam } \\
\text { soal, sehingga data ys dimarukcan memang akurat. }\end{array}$ & $\begin{array}{l}\text { By finding the data first before writing the problem, } \\
\text { so the data used is accurate. }\end{array}$ \\
\hline AAL-17 & $\begin{array}{l}\text { Data yang saya ambil lounapan bersitat fakta dan } \\
\text { Saya wi... } \\
\text { kepada diri saya terlecit danely }\end{array}$ & $\begin{array}{l}\text { The data that I take / use are factual, and I test myself } \\
\text { first. }\end{array}$ \\
\hline AAL-21 & 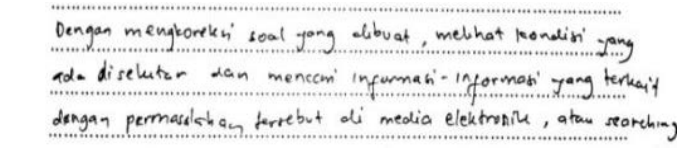 & $\begin{array}{l}\text { By correcting the questions made, look at the } \\
\text { conditions around, and search for information } \\
\text { related to the problem in electronic media. }\end{array}$ \\
\hline
\end{tabular}


Table 5. Implementation of Self-Assessment (Question No. 7)

\begin{tabular}{|c|c|c|}
\hline $\begin{array}{l}\text { Respondent } \\
\text { Code }\end{array}$ & Answers of Students & Translation \\
\hline AAL-06 & 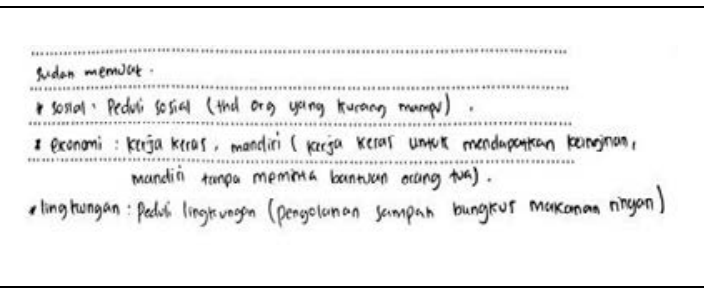 & $\begin{array}{l}\text { Already loaded. } \\
\text { Social: social care (towards people who are less } \\
\text { fortunate) } \\
\text { Economy: hard work, independent (work hard to get } \\
\text { what you want, be independent without asking your } \\
\text { parents for help) } \\
\text { Environment: care for the environment (processing } \\
\text { snack wrappers) }\end{array}$ \\
\hline AAL-13 & 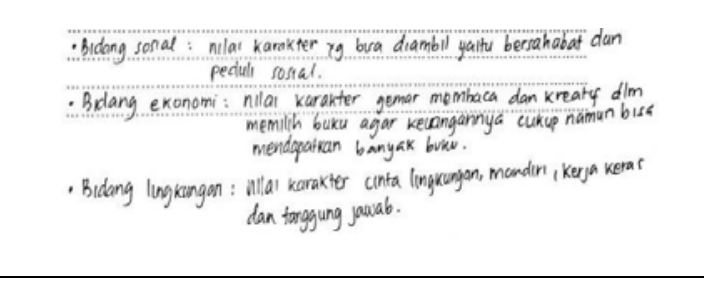 & $\begin{array}{l}\text { The social field: the character values that can be } \\
\text { taken are friendly and social care } \\
\text { In economics: the character values are liking reading } \\
\text { and be creative in choosing books so that the budget } \\
\text { is sufficient and get many books. } \\
\text { The field of environment: the character values are } \\
\text { loving the environment, independent, hard work and } \\
\text { responsible. }\end{array}$ \\
\hline AAL-17 & 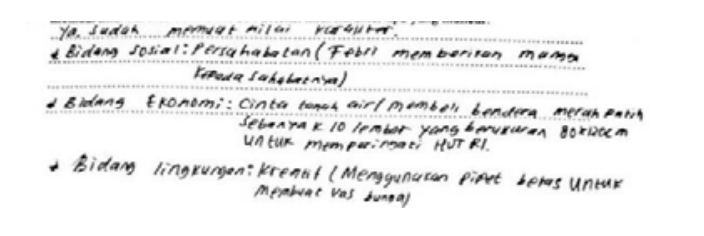 & $\begin{array}{l}\text { Yes, the character value is already included. } \\
\text { Social field: friendship (Febri gives mango to his } \\
\text { best friends) } \\
\text { Economic sector: loving the motherland (buy } 10 \text { red } \\
\text { and white flags of } 80 \times 120 \mathrm{~cm} \text { to commemorate } \\
\text { Indonesian Independence Day) }\end{array}$ \\
\hline AAL-21 & 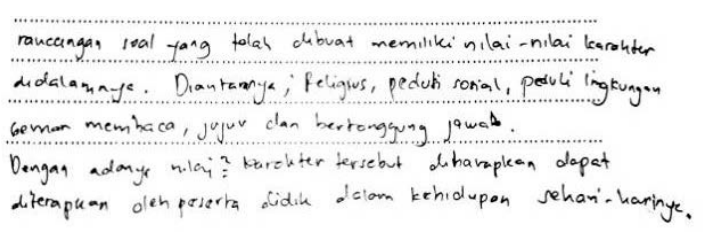 & $\begin{array}{l}\text { The question designed that has been made has } \\
\text { character values in it, including religious, social } \\
\text { care, care for the environment, love reading, honest, } \\
\text { and responsible. } \\
\text { These character values are expected to be applied by } \\
\text { students in their daily lives. }\end{array}$ \\
\hline
\end{tabular}

Question No 7:

"Double-check the problem that you designed, does the question contain character values? Explain and detect which character values appear? "

The questions designed by students were ESD-based mathematics test questions. Therefore, in the questions designed contain character values. Students filled in the assessment as learning to ensure that each question designed contains character values.

Based on students' answers, almost all students have been able to integrate character values into mathematical problems in the social, economic, and environmental fields. Even, there is a draft question consisting of more than one character value. The character values are implicitly and not clearly stated in the sentence used. The participants hope that when students work on a given mathematics problem, they can interpret a character value in it. Hence, when solving the given mathematical problem, students can solve mathematical problems and get the moral message through the character values in the problem.

Thus, in general, students have been able to design mathematics test questions based on ESD. This finding is indicated by the questions designed that are not only applying mathematical problems to the social, economic, and environmental aspects but also contain character values.

After students have designed the mathematics test questions, they review the draft questions to better ensure the accuracy of the questions, the selected aspects, the data, and so on by filling out the Peer-Assessment sheet. The Peer-Assessment Sheet aims to enable students to help their peers to re-examine the questions designed. It is expected that the correction results by peers to the questions designed by the students will inform us of any discrepancy or lack of data on the questions designed. Table 6 displays the pairing of Peer-Assessment.

Table 6. Peer-Assessment Filling Pair

\begin{tabular}{|c|l|}
\hline No & Peer-Assessment filling pair \\
\hline 1. & AAL-06 pairing with AAL-17 \\
\hline 2. & AAL-13 pairing with AAL-21 \\
\hline 3. & AAL-17 pairing with AAL-06 \\
\hline 4. & AAL-21 pairing with AAL-13 \\
\hline
\end{tabular}

Table 6 reveals that two students examined each other's questions. The Peer-Assessment is expected to examine deficiencies and inaccuracies in the design of mathematics problems of their peers. The following is a description of the data obtained through the Peer-Assessment process conducted by pre-service mathematics teachers. 


\section{Question No 1:}

"Explain which parts of the question designed by your colleague have integrated problems in the social field?" (When a student evaluates his colleague)

Table 7 shows that all students have been able to examine which parts of the questions designed by their peers integrating problems in the social field. There is also a matching answer between the Self-Assessment in Table 5 and the Peer-Assessment in Table 10. This shows that students have been able to identify parts of the questions designed that integrate problems in the social field. It is then supported by a similar answer when their colleague examined the draft question. Therefore, it can be concluded that students have been able to design Mathematics test questions based on ESD and have been able to ensure that the correct questions concerning the application of mathematics in social aspects.

\section{Question No 2:}

"Explain which parts of the question designed by your colleague have integrated problems in economics?" (When a student evaluates his colleague)

Table 8 contains the results of examinations by the colleagues about the design of mathematical problems integrated into economic aspects. To check the conformity between the Self-Assessment and Peer-Assessment examinations, the answers in Table 5 and Table 11 are compared. Overall, the answers given in Table 5 are similar to the answers in Table 11, including the incorrect placement of aspects by AAL-21. So, in this case, the inaccuracy of the aspect placement was not realized by AAL-21 students, even though it has been through the examination process twice: the Self-Assessment and Peer-Assessment stages. Students and colleagues are alike in thinking that the design of economic aspects designed by AAL-21 is appropriate.

Table 7. Application of Peer-Assessment (Question No. 1)

\begin{tabular}{|c|c|c|}
\hline Respondent Code & Answers of Students & Translation \\
\hline AAL-06 & - pemberiang buon mangga lapada temannya. & Giving mango to his friend. \\
\hline AAL-13 & 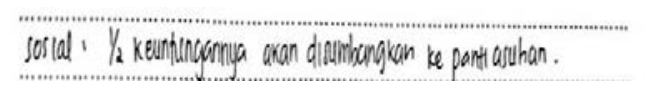 & $\begin{array}{c}\text { Social : } \frac{1}{2} \text { the profits will be donated to } \\
\text { the orphanage. }\end{array}$ \\
\hline AAL-17 & dsorial : tentang kefedulian thd kefutuhan serame & $\begin{array}{c}\text { Social: about caring for the needs of } \\
\text { others }\end{array}$ \\
\hline AAL-21 & sinta membetikon pembantunga donat $I$.CO & Sinta buys her maid J.CO donuts \\
\hline
\end{tabular}

Table 8. Application of Peer-Assessment (Question No. 2)

\begin{tabular}{|c|c|c|}
\hline Respondent Code & Answers of Students & Translation \\
\hline AAL-06 & * harga bendera & Flag price \\
\hline AAL-13 & Setiap kelas mengumpulkan uang selklasnys & Each class collects money sincerely \\
\hline AAL-17 & Harga sebuah laptop & The price of a laptop \\
\hline AAL-21 & 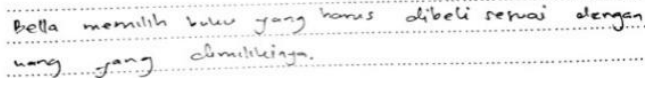 & $\begin{array}{l}\text { Bella chooses books to buy according to the } \\
\text { money she has }\end{array}$ \\
\hline
\end{tabular}


Table 9. Application of Peer-Assessment (Question No 3)

\begin{tabular}{|c|c|c|}
\hline Respondent Code & Answers of Students & Translation \\
\hline AAL-06 & - pengolanan apee menjadi vas bungu & Processing straws into flower vases. \\
\hline AAL-13 & Bopyak buku yarg akan doumbangkan. & Many books will be donated. \\
\hline AAL-17 & Pengolahen sampah bungkus makanan rigann & Processing of snack food wrappers \\
\hline AAL-21 & Pall Qudi memintm bantw anaknyn berocol trenam. & $\begin{array}{l}\text { Mr. Budi asked to help his children } \\
\text { grow crops }\end{array}$ \\
\hline
\end{tabular}

Table 10. Application of Peer-Assessment (Question No 5)

\begin{tabular}{|c|c|c|}
\hline Respondent Code & Answers of Students & Translation \\
\hline AAL-06 & 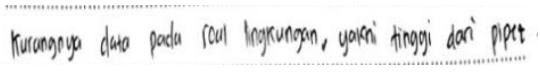 & $\begin{array}{l}\text { Lack of data on environmental problems, namely the } \\
\text { height of the straws. }\end{array}$ \\
\hline AAL-13 & 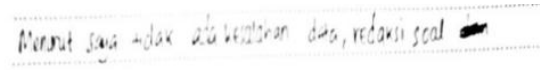 & $\begin{array}{l}\text { In my opinion, there are no data errors, editorial } \\
\text { questions }\end{array}$ \\
\hline AAL-17 & Tidak ada kesalahan & There is no mistake \\
\hline AAL-21 & 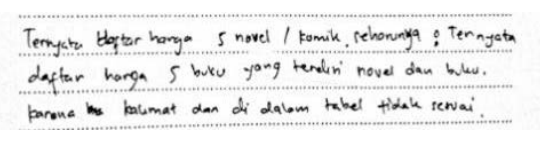 & $\begin{array}{l}\text { It turns out the price list of five novels/comics. } \\
\text { Supposedly, it turns out the price list of five books } \\
\text { consisting of novels and books because the sentences } \\
\text { and tables do not match. }\end{array}$ \\
\hline
\end{tabular}

Question No 3:

"Explain which parts of the question designed by your colleague have integrated problems in the environmental field?" (When a student evaluates his colleague)

Table 9 indicates that the answer between the Self-Assessment in Table 5 confirms the Peer-Assessment in Table 12, including the incorrect placement of mathematical problems in environmental aspects. This happened to AAL-13, who also that "the number of books donated" was classified as environmental. These points will be followed up with an examination on the completion of Peer-Assessment no. 5 and 8 below.

Question No. 5:

"Check the questions designed by your colleague. Are there data errors, problem editors, calculations, alternative answers, or scoring guidelines? If there is, explain in which parts, what type of errors, why it is wrong, and what should be the correct one? "(When a student evaluates his/her peers)

Table 10 displays the result of a colleague's search for data errors, question editor, and calculations in the question designed. Table 4 explains that there are deficiencies and inaccuracies in the data of in AAL-17, that the straw height information is not available and the size of the flower vase that is not provided. So the data provided is inaccurate and incomplete. It turns out that in this Peer-Assessment process, colleagues acknowledge this, AAL-06 said that "the lack of data on environmental issues, namely the height of the straw". After a colleague found this deficiency in the question designed, then AAL-17 realized it and acknowledged that there was indeed a lack of data in the question. Then there was also a response from AAL-21 who advised AAL-13 in terms of preparing question editors. According to AAL-21, the word "novel or comic" used by AAL-13 should be replaced by the word "novel and comic". 
Table 11. Application of Peer-Assessment (Problem No 8)

\begin{tabular}{|c|c|c|}
\hline $\begin{array}{l}\text { Respondent } \\
\text { Code }\end{array}$ & Answers of Students & Translation \\
\hline AAL-06 & 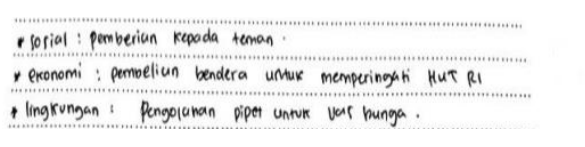 & $\begin{array}{l}\text { Social: giving to friends } \\
\text { Economy: purchasing flags to commemorate the Republic of } \\
\text { Indonesia Independence day } \\
\text { Environment: processing straw for flower vases. }\end{array}$ \\
\hline AAL-13 & $\begin{array}{l}\text { Menurut saya penerapan mlal karakter pd rancangan soal } \\
\text { matematik a oleh teman sejawat sudah sesual dg acuan nilail } \\
\text { karakter yauy nda di dalam kehidupan sehari-hari. }\end{array}$ & $\begin{array}{l}\text { In my opinion, the application of character values in the } \\
\text { mathematical questions designed by colleagues is in } \\
\text { accordance with the reference of character values in everyday } \\
\text { life. }\end{array}$ \\
\hline AAL-17 & $\begin{array}{l}\text { Meurut save penerapan nilai karakternya sudah } \\
\text { tepat. }\end{array}$ & In my opinion, the application of the character value is correct. \\
\hline AAL-21 & 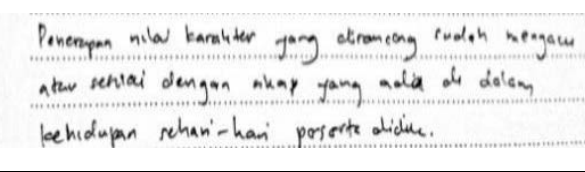 & $\begin{array}{l}\text { The application of character values designed already refers to } \\
\text { or in accordance with the attitudes in the daily lives of students. }\end{array}$ \\
\hline
\end{tabular}

Question No. 8:

"How do you apply the character values to your mathematics problem designed?"

(When a student evaluates his/her peers)

Table 11 shows that colleagues have examined the strongest character value in the mathematical problems designed. The explanation of the character values is in line with the explanation of the character values by students in Table 5. However, there are also deficiencies in the character values that are not identified by peers. Overall, students and colleagues have determined and choose the character values that match the questions designed.

The following is the data distribution of the character values for each aspect applied: social, economic, and environmental.

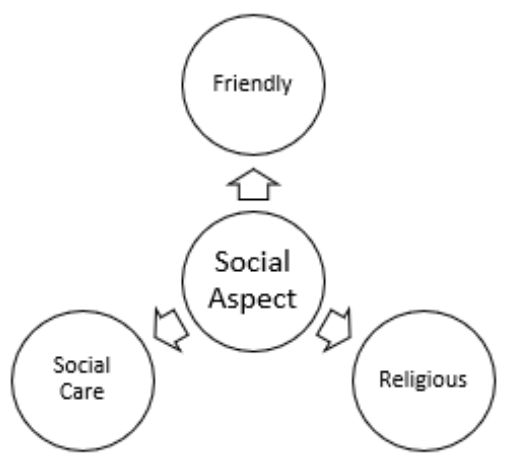

Figure 5. Spread of Character Values in Social Aspect
Figure 5 shows three character values integrated into the Mathematics Education for Sustainability Development based on the test questions. Of the three character values, social care is the most frequently used. Thus, it can be assumed that the value of social care character is identical to the application of mathematical problems in the social aspect. Most of the mathematics test questions designed by students indeed describe social care through sharing activities with others. Mathematical material widely used in applying social problems is social arithmetic.

Figure 6 shows the character values that are integrated into mathematical problems in economic aspects. It reveals eight character values used by students in the design of mathematics test questions. However, of the eight character values, none is dominant. The five character values are only used once by one student. It is different from the character value of social care that was used by more than one student in Figure 8. Thus, many character values can be explored in the application of mathematical problems to the economic aspects.

Figure 7 shows the character values in environmental aspects. It illustrates seven character values that appear in the design of mathematics problems, with caring for the environment is the most dominant. This is certainly relevant to the environmental aspect. The pre-service teachers hope that through their design of mathematical problems, students will have the character of caring for the environment. 


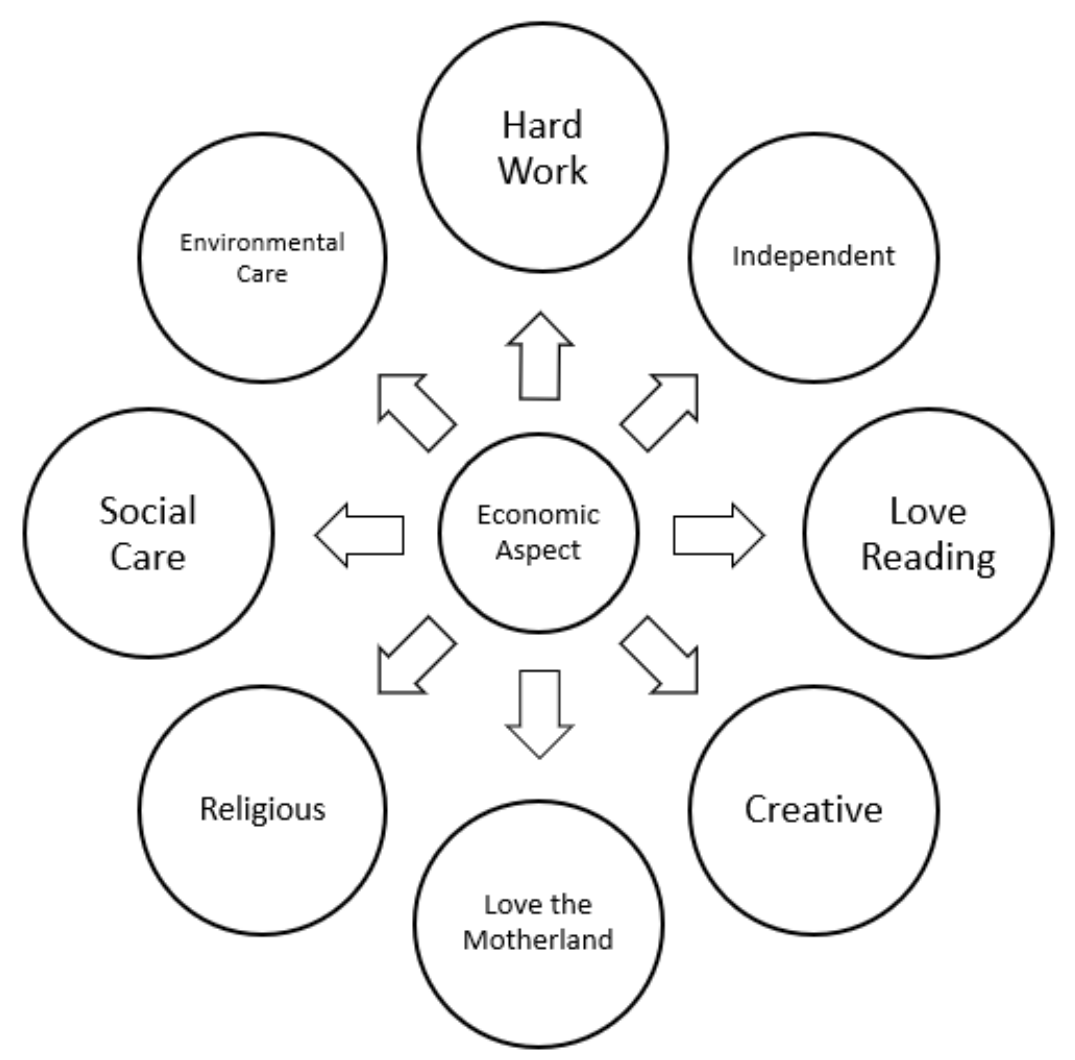

Figure 6. Spread of Character Values in Economic Aspect

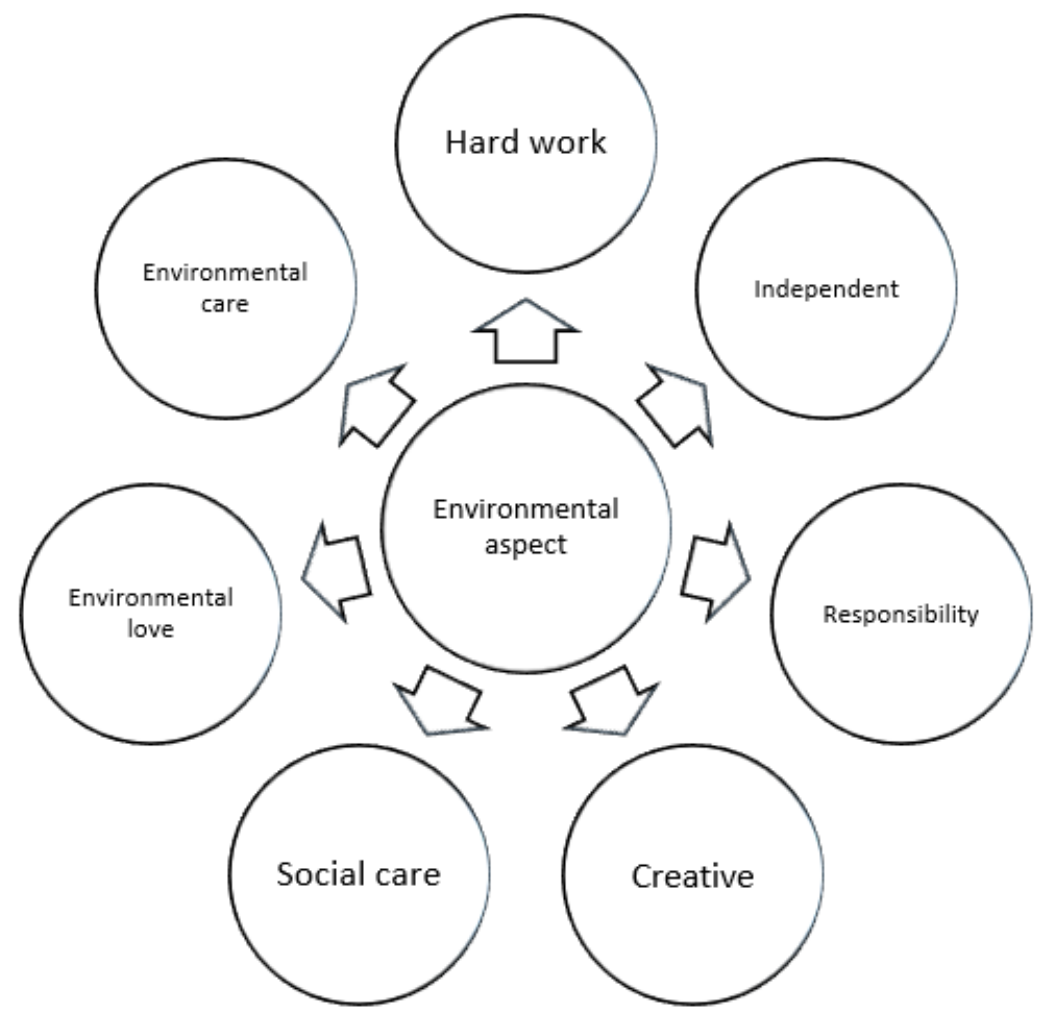

Figure 7. Spread of Character Values in Environmental Aspect 
The following is the distribution of mathematics materials chosen by the pre-service teachers to be used in the design of mathematics test questions. The description of the distribution of mathematical material serves to investigate the mathematical materials that can be applied to social, economic, and environmental aspects. It seeks the possibility concerning the mathematical materials that have originally predicted to be applied in life could actually be applied in real life.

Based on Figures 8, 9, and 10, it can be seen that the mathematics materials applied in the design of Mathematics questions based on ESD are mainly easy and moderate level materials. It was confirmed through the interview process that the pre-service teachers only think of the easy and medium level mathematics material. Students also found it difficult to design mathematics problems using difficult materials, such as limits, integrals, derivatives, logarithms, trigonometry, etc. This material is classified as difficult for students, and they also found it hard to find ideas to apply them in social, economic, and environmental aspects of life.

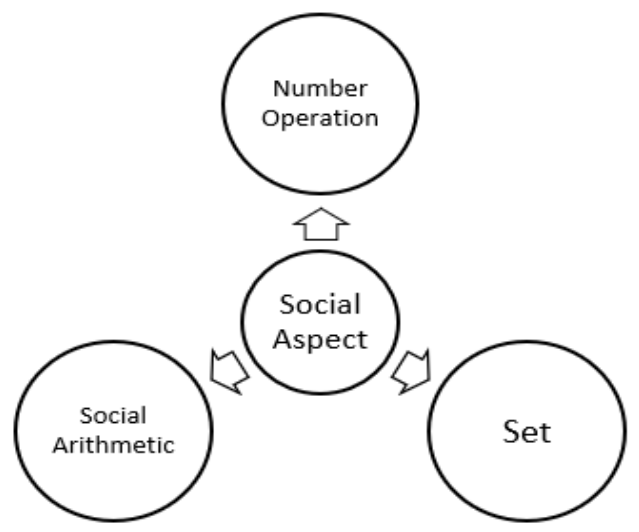

Figure 8. Dissemination of Mathematical Material in Social

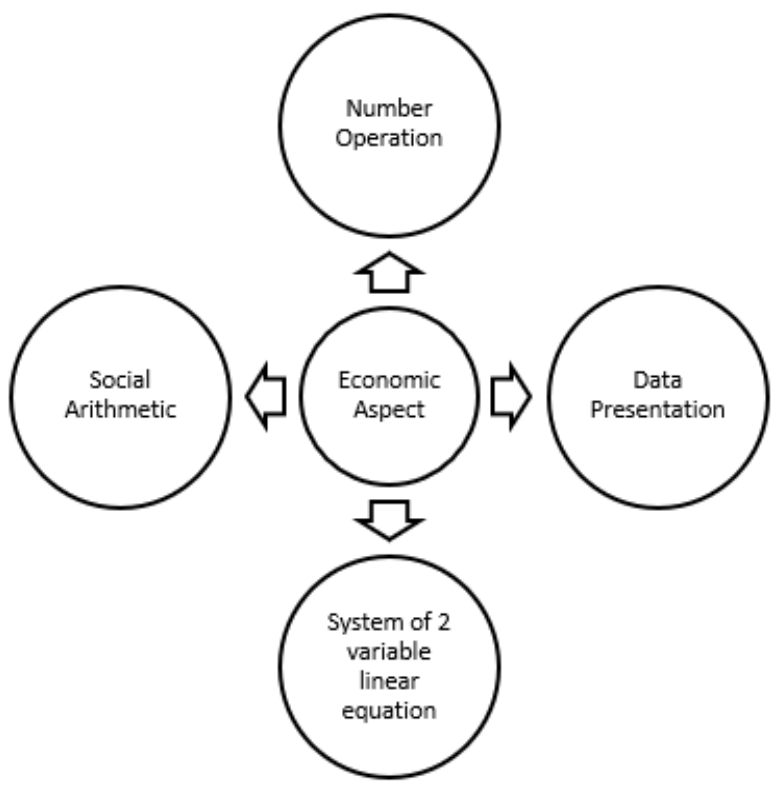

Figure 9. Dissemination of Mathematical Material in Economics

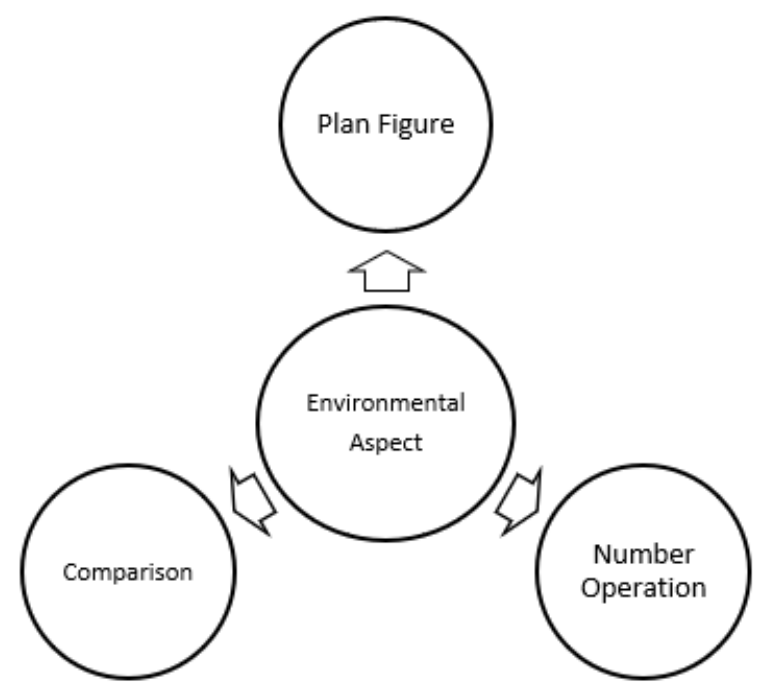

Figure 10. Dissemination of Mathematical Material in Environmental

Based on the research results, the analysis of the data concerning mathematics test questions designed by pre-service teachers, and the in-depth interviews, several conclusions are drawn as follows.

a). Assessment as Learning plays an important role in supporting the pre-service teachers to conduct feedback and monitor the work done.

b). For the economic aspect, the problem raised is mainly about the price of items. However, many other themes can be used.

c). The participants found it hard to design a mathematical test instrument by applying mathematical problems in environmental and social aspects.

d). The participants said that the environmental and social aspects were difficult to distinguish. Thus, some designs of mathematical test instruments applying the environmental aspect are inappropriate. The design should be classified into the application of mathematical problems to the social aspect.

e). The pre-service teachers found it more difficult to fill out Peer-Assessment than Self-Assessment because they must first study the instrument designed. Sometimes, there are differences of opinion regarding the meaning of the instrument designed.

f). Researchers assume that the pre-service teachers had difficulty completing the Self-Assessment because they unconsciously think that the instrument designed is correct. They feel they have designed it correctly. They have repeatedly read the question editor, and the data has been a trusted search process. However, they cannot detect errors when filling in Self-Assessment.

g). In general, the Self-Assessment and Peer-Assessment help detect errors and deficiencies in designing a good quality mathematical test instrument. Yet, there are still shortcomings in its implementation. Nevertheless, this Self-Assessment and Peer-Assessment are useful to support the assessment as a learning process. 
h). Students have been able to design Mathematics test instruments based on ESD. However, the selection of character values and the mathematical materials used have not been varied. Also, the pre-service teachers have not produced a mathematical test instrument with a high degree of difficulty.

i). It is important to familiarize the pre-service teachers with designing Mathematical Education test instrument based on ESD. It is also hoped that they will be sensitive to daily life problems that can be used in mathematics problems based on ESD.

In short, it can be said that Assessment as Learning plays an important role in supporting the learning process, especially in evaluation. Assessment as Learning is useful as a tool to monitor and review or provide feedback on the learning process and outcomes. Assessment as Learning is useful for checking mistakes and deficiencies in Learning. So, it is useful in supporting the learning process and minimizing errors.

Assessment is used as Learning, meaning that the assessment conducted is also a learning process because it functions as a monitoring tool to minimize errors. Pre-service mathematics teachers learn to correct their work and their peers'. Thus, there are two assessment processes carried out to support good Learning and produce quality learning outcomes. That is the concept of Assessment as Learning found based on the results of this study.

The assessments carried out previously in the learning process are the Assessment of Learning and Assessment for Learning. Initially, Assessment as Learning only has the smallest part in the assessment pyramid. However, after the reconfiguration, Assessment as Learning has the largest share in the reconfigured assessment. This shows that Assessment as Learning currently has the biggest role and benefit. However, this still requires habituation and learning for the Assessment as Learning process to be carried out properly. Therefore, researchers should disseminate information about Assessment as Learning so that more people understand and use it.

\section{Conclusion}

Based on the results and discussion, it can be concluded that pre-service mathematics teachers have been able to produce a mathematical test instrument design based on Education for Sustainable Development (ESD). This finding is demonstrated by the design of mathematical test instruments, which not only apply the social, economic, and environmental aspects but also contain character values, the special features of the Mathematical Education test questions based on ESD.

In supporting students to design Mathematical Education test instruments based on ESD, the Assessment as Learning serves as a tool to check and review the design of mathematical test instruments created. The Assessment as Learning, conducted in two stages: Self-Assessment and Peer-Assessment, is useful for detecting errors, inaccuracies or deficiencies of the design of mathematical test instruments.

Assessment as Learning plays an important role in the learning process. Assessment should not only as Assessment of Learning or Assessment for Learning. It is also more useful if its role is Assessment as Learning. Assessment is not only used at the beginning or the end of Learning, but also during Learning, so that it is called Assessment as Learning. Assessment as Learning can be a tool to monitor or check the learning process and can minimize errors. Assessment as Learning in this study is limited in its use in preparing mathematics test questions based on ESD.

\section{Acknowledgements}

We are very grateful to pre-service mathematics teachers for all information assistance provided.

\section{REFERENCES}

[1] A. Ghaicha, "Theoretical Framework for Educational Assessment : A Synoptic Review," J. Educ. Pract., vol. 7, no. 24, pp. 212-231, 2016.

[2] P. Black and D. Wiliam, "Inside the black box: Raising standards through classroom assessment," Phi Delta Kappan, vol. 92, no. 1, pp. 81-90, 2010, doi: $10.1177 / 003172171009200119$.

[3] D. Nicol and D. Macfarlance-Dick, "a Theoretical Model and Seven Principles of Good Feedback Practice .," High. Educ. Acad. Accessed, vol. 8, no. i, pp. 1-9, 2006.

[4] D. Boud, R. Cohen, and J. Sampson, "Peer learning and assessment,” Assess. Eval. High. Educ., vol. 24, no. 4, pp. 413-426, 1999, doi: 10.1080/0260293990240405.

[5] S. K. Kesianye, "The Three Perspectives of Integrating Assessment and Instruction in the Learning of School Mathematics," J. Educ. Pract., vol. 6, no. 19, pp. 212-214, 2015.

[6] H. A. Alkharusi and S. Al-Hosni, "Perceptions of classroom assessment tasks: An interplay of gender, subject area, and grade level," Cypriot J. Educ. Sci., vol. 10, no. 3, p. 205, 2015, doi: 10.18844/cjes.v1i1.66.

[7] M. Budiyono, “済無 No Title No Title,” J. Chem. Inf. Model., vol. 53, no. 9, pp. 1689-1699, 2019, doi: 10.1017/CBO9781107415324.004.

[8] D. Boud, "Sustainable assessment: Rethinking assessment for the learning society,” Stud. Contin. Educ., vol. 22, no. 2, pp. 151-167, 2000, doi: 10.1080/713695728.

[9] J. L. Herman and D. C. D. Klein, "Assessing opportunity to learn: a California example,” Natl. Cent. Res. Eval. , Stand. , 
Student Test. (CRESST), vol. 453, no. 310, 1997.

[10] K. Wolf, J. Dunlap, and E. Stevens, “Ten Things Every Professor Should Know about Assessment,” J. Eff. Teach., vol. 12, no. 2, p. 65, 2012.

[11] L. Sandham and R. Burger, “Assessering as leer,” 2013.

[12] L. Allal, "Assessment and the co-regulation of learning in the classroom,” Assess. Educ. Princ. Policy Pract., vol. 00, no. 00, pp. 1-18, 2019, doi: 10.1080/0969594x.2019.16094 11.

[13] L. M. Earl, "Assessment For Learning ; Assessment As Learning: Changing Practices Means Changing Beliefs," Assess. Learn., vol. 80, no. 2, pp. 2-6, 1998.

[14] L. Earl and S. Katz, Rethinking Classroom Assessment with Purpose in Mind. 2006.

[15] K. Venetia, “Could Student' s Evaluation be a Pleasant and Effective Process ?," vol. 3, no. 2, pp. 51-56, 2016, doi: 10.20448/journal.509/2016.3.2/509.2.51.56.
[16] D. Boud and R. Soler, "Sustainable assessment revisited," Assess. Eval. High. Educ., vol. 41, no. 3, pp. 400-413, 2016, doi: 10.1080/02602938.2015.1018133.

[17] R. Bourke and M. Mentis, "Self-assessment as a process for inclusion,” Int. J. Incl. Educ., vol. 17, no. 8, pp. 854-867, 2013, doi: 10.1080/13603116.2011.602288.

[18] K. J. Topping, “Peer assessment,” Theory Pract., vol. 48, no. 1, pp. 20-27, 2009, doi: 10.1080/00405840802577569.

[19] I. Jones and L. Alcock, "Peer assessment without assessment criteria,” Stud. High. Educ., vol. 39, no. 10, pp. 1774-1787, 2014, doi: 10.1080/03075079.2013.821974.

[20] R. Mckeown, “ESD Toolkit version 2,” pp. 1-142, 2002.

[21] UNESCO, Education for Sustainable Development Goals. 2017.

[22] I. Widiati and D. Juandi, "Philosophy of mathematics education for sustainable development," in Journal of Physics: Conference Series, 2019, doi: 10.1088/1742-6596/ 1157/2/022128. 